\title{
Mannitol Metabolism in Agaricus bisporus: Purification and Properties of Mannitol Dehydrogenase
}

\author{
By N. MORTON, A. G. DICKERSON AND J. B. W. HAMMOND*† \\ Department of Biochemistry, Imperial College, London $S W 72 A Z, U K$
}

(Received 18 March 1985; revised 27 June 1985)

\begin{abstract}
Mannitol dehydrogenase (EC 1.1.1.138) has been purified to homogeneity from fruit bodies of Agaricus bisporus. $M_{\mathrm{r}}$ values of 115000 were determined by gel filtration and 130000 by rate zonal ultracentrifugation. The sedimentation coefficient is $6.5 \mathrm{~S}$. The native protein is composed of four subunits of $M_{\mathrm{r}} 29000$. The enzyme is specific for NADP, and shows low activity with sorbitol. Normal Michaelis-Menten kinetics are exhibited for both mannitol and NADP, giving $K_{\mathrm{m}}$ values of $16.2 \mathrm{mM}$ and $36 \mu \mathrm{M}$ respectively at $\mathrm{pH} 7.0$. The $K_{\mathrm{m}}$ value for NADPH is $38.5 \mu \mathrm{M}$ and that for fructose approximately $1.2 \mathrm{M}$. The $V_{\max }$ is $591 \mu \mathrm{M} \mathrm{min}{ }^{-1}$ (mg protein) $)^{-1}$ for mannitol synthesis and $5 \mu \mathrm{mol} \mathrm{min}^{-1}(\mathrm{mg} \text { protein })^{-1}$ for fructose synthesis at $\mathrm{pH} 7 \cdot 0$. Inhibition of fructose synthesis by NADPH is stronger than inhibition of mannitol synthesis by NADP. The results are discussed with respect to the control of enzyme activity under physiological conditions.
\end{abstract}

\section{INTRODUCTION}

Mannitol synthesis and accumulation are major features of the growth of Agaricus bisporus fruit bodies (Rast, 1965; Hammond \& Nichols, 1976). Mannitol is synthesized from fructose using NADPH as cofactor. The enzyme responsible, mannitol dehydrogenase (EC 1.1.1.138), has been partially purified and characterized previously (Edmundowicz \& Wriston, 1963; Ruffner et al., 1978). However, there are inconsistencies in the published results which may be due to incomplete purification. To advance our knowledge of the function and control of mannitol metabolism in fruit body growth, it was necessary to obtain accurate kinetic data and to assess the possibilities of in vivo regulation of the enzyme. The results of a programme of complete purification and characterization are reported here.

\section{METHODS}

A. bisporus (strain 'Darlington's 649') was grown in plastic buckets in compost prepared at the Glasshouse Crops Research Institute. Fruit bodies (stage 2-3; Hammond \& Nichols, 1976) were thinly sliced, frozen in liquid nitrogen, and stored at $-20^{\circ} \mathrm{C}$ until used.

$M T L D H$ purification. All operations were done at $4{ }^{\circ} \mathrm{C}$. The procedure for a typical purification was as follows. Frozen slices of fruit body $(340 \mathrm{~g})$ were thawed and homogenized in $25 \mathrm{ml} 10 \mathrm{~mm}$ - Tris/ $\mathrm{HCl}$ buffer, $\mathrm{pH} \mathrm{7.5,}$ containing $50 \mathrm{~mm}$-2-mercaptoethanol and $0.25 \mathrm{~mm}$-phenylmethylsulphonyl fluoride (buffer 1 ). The homogenate was centrifuged at $15000 \mathrm{~g}$ for $30 \mathrm{~min}$ and the supernatant retained. Nucleic acids were precipitated by addition of excess protamine sulphate to give a final concentration of approximately $0 \cdot 25 \%(\mathrm{w} / \mathrm{v})$. The suspension was centrifuged as above. Protein was then precipitated from the supernatant by slow addition of ammonium sulphate. The fraction precipitating between 326 and $516 \mathrm{~g}$ ammonium sulphate $\mathrm{l}^{-1}$ was centrifuged down and dissolved in a minimum volume (approx. $5 \mathrm{ml}$ ) of buffer 1 . The preparation was applied to a Sephadex G100 column $(33 \times$ $2.5 \mathrm{~cm}$ ) equilibrated with buffer 1 , and was eluted with the same buffer. The active fractions, which eluted in the

$\dagger$ Present address: Department of Biochemistry, Rothamsted Experimental Station, Harpenden, Hertfordshire AL5 2JQ, UK.

Abbreviation: MTLDH, mannitol dehydrogenase. 
void volume, were pooled and concentrated to approximately $8 \mathrm{ml}$ in an Amicon ultrafilter with a PM10 membrane. The concentrated sample was applied to a DEAE-Sephadex A-50 column $(30 \times 1.4 \mathrm{~cm})$ equilibrated with buffer 1 , and was eluted with the same buffer. The active fractions, which eluted in the void volume, were pooled and applied to a column $(5 \times 1 \mathrm{~cm})$ of Matrex Gel Red A (Amicon) equilibrated with buffer 1 . The column was washed with the same buffer until no further protein was eluted. The bound protein was eluted with a linear $100 \mathrm{ml}$ gradient of $0-4 \mathrm{M}-\mathrm{NaCl}$ in buffer 1 . The activity eluted as a single peak at $2 \cdot 5-3 \cdot 0 \mathrm{M}-\mathrm{NaCl}$. The active fractions were pooled and dialysed against buffer 1 containing $10 \mathrm{mM}-2$-mercaptoethanol and $0.05 \mathrm{~mm}-$ phenylmethylsulphonyl fluoride. The retentate was concentrated by ultrafiltration. Glycerol was added to a concentration of $50 \%(\mathrm{v} / \mathrm{v})$, and the preparation stored at $-20^{\circ} \mathrm{C}$. There was no significant loss of activity after storage for 1 month in this form. Protein content of solutions was determined by the method of Lowry.

$M T L D H$ assay. MTLDH was assayed by monitoring oxidation of NADPH or reduction of NADP at $340 \mathrm{~nm}$. Assays were done at $25^{\circ} \mathrm{C}$ in a total volume of $1 \mathrm{ml}$. The reduction of fructose was assayed by incubating a sample of extract in $50 \mathrm{~mm}$-Tris/ $\mathrm{HCl}$ buffer, $\mathrm{pH} 7.5$, containing $800 \mathrm{~mm}$-fructose and $0.25 \mathrm{~mm}$-NADPH. The oxidation of mannitol was assayed by incubating extract in $50 \mathrm{mM}-\mathrm{Na}_{2} \mathrm{CO}_{3}$ buffer, $\mathrm{pH} 10 \cdot 4$, containing $200 \mathrm{mM}-\mathrm{D}-\mathrm{mannitol}$ and $1 \mathrm{~mm}-\mathrm{NADP}$. One unit of activity is the amount of enzyme which catalyses the oxidation of $1 \mu \mathrm{mol}$ NADPH $\min ^{-1}$, or the reduction of $1 \mu \mathrm{mol} \mathrm{NADP} \min ^{-1}$ in the above systems. Assays were done in the direction of fructose reduction except where stated otherwise.

Kinetics. For the determination of kinetic parameters, the above assay system was used with pure enzyme, except that while one substrate concentration was varied the other substrate was held at a saturating concentration (NADP $=1 \mathrm{~mm} ; \mathrm{NADPH}=0.25 \mathrm{mM}$; mannitol $=200 \mathrm{mM}$ ). The fructose concentration was $800 \mathrm{~mm}$ since higher concentrations led to substrate inhibition (see Results). Kinetic parameters were determined between pH 6.5 and 11.0 , in $50 \mathrm{mM}$ Tris/maleate, Tris/ $\mathrm{HCl}$ or $\mathrm{Na}_{2} \mathrm{CO}_{3}$ buffers as appropriate.

Determination of $k_{e q}$. Pure enzyme $(10 \mu \mathrm{l}, 4.4 \mu \mathrm{g})$ was incubated with $36.9 \mu \mathrm{M}-\mathrm{NADP}$ and $500 \mu \mathrm{M}-\mathrm{D}-\mathrm{mannitol}$ in $1.0 \mathrm{ml} 50 \mathrm{~mm}-\mathrm{Na}_{2} \mathrm{CO}_{3}$ buffer, $\mathrm{pH} 10 \cdot 18$. The reaction was allowed to reach equilibrium as determined by a constant absorbance at $340 \mathrm{~nm}$. The increase in concentration of NADPH was calculated from the increase in $A_{340}$, and the molar absorption coefficient of NADPH $\left(6220 \mathrm{M}^{-1} \mathrm{~cm}^{-1}\right)$. Equimolar decreases in NADP and mannitol concentrations, and a molar stoichiometry of $1: 1$ between NADPH and fructose produced, were assumed (Edmundowicz \& Wriston, 1963). The concentration of $\mathrm{H}^{+}$ions was calculated from the measured $\mathrm{pH}$.

$M_{r}$ determination. A sample of purified enzyme $\left(0.25 \mathrm{ml} ; 0.33 \mathrm{mg} \mathrm{ml}^{-1}\right)$ was applied to a column $(120 \times 1.5 \mathrm{~cm})$ of Sephadex G200 equilibrated with $50 \mathrm{~mm}$-Tris/HCl buffer, $\mathrm{pH} \mathrm{7.5}$. The enzyme was eluted with the same buffer. Protein in the fractions was detected by absorbance at $280 \mathrm{~nm}$ and enzyme activity by the assay described above. Standard proteins were: catalase $\left(M_{\mathrm{r}} 240000\right)$; horse liver alcohol dehydrogenase (150000); bovine serum albumin (66000); ovalbumin (45000); and horse myoglobin (17000). Analytical ultracentrifugation and rate zonal ultracentrifugation were done as described by Hammond (1985a).

Electrophoresis. Non-denaturing PAGE was done in $8 \%(\mathrm{w} / \mathrm{v})$ polyacrylamide gels $(1 \%$ crosslinked) with $40 \mathrm{~mm}$-acetate buffer, pH 5.0. A reservoir buffer of $40 \mathrm{~mm}$-acetate, pH 5.0, was used. MTLDH activity was detected by incubating the gels for $5-20 \mathrm{~min}$ at $25^{\circ} \mathrm{C}$ in $50 \mathrm{~mm}-\mathrm{Na}_{2} \mathrm{CO}_{3}$ buffer, pH $10 \cdot 4$, containing $100 \mathrm{~mm}-\mathrm{D}-$ mannitol, 1 mM-NADP, $0.002 \%$ phenazine methosulphate and $0.032 \%$ nitroblue tetrazolium. Protein bands were detected using Coomassie blue. SDS-PAGE was done in $8 \%$ polyacrylamide gels ( $1 \%$ crosslinked) containing $0 \cdot 1 \% \mathrm{SDS}$, with $40 \mathrm{mM}$-potassium phosphate buffer, $\mathrm{pH} 7 \cdot 2$. The reservoir buffer was $0 \cdot 1 \mathrm{M}$-potassium phosphate, pH 7.2, containing $0.01 \mathrm{M}$-EDTA and $0.1 \%$ SDS. Samples were prepared by heating to $100^{\circ} \mathrm{C}$ with reservoir buffer and $1 \%$ 2-mercaptoethanol $(1: 1, \mathrm{v} / \mathrm{v}) . M_{\mathrm{r}}$ standards were: Bacillus stearothermophilus methionyl-tRNA synthetase (90000); bovine serum albumin (66000); Bacillus subtilis tryptophanyl-tRNA synthetase (47000); rabbit muscle aldolase (40000); bovine chymotrypsinogen (25700) and lysozyme (14300). The Bacillus enzymes were gifts from Dr C. J. Bruton, Imperial College, London, UK.

Paper chromatography of reaction products. The incubation products of the mannitol dehydrogenase reaction were applied to Whatman no. 1 paper and separated by descending chromatography for $22 \mathrm{~h}$ at room temperature in ethyl methyl ketone/acetic acid/borate saturated water $(9: 1: 1$, by vol.). D-Fructose, D-glucose, D-mannitol and sorbitol markers were also run. After drying, the chromatogram was dipped in a saturated solution of lead tetraacetate in glacial acetic acid and allowed to dry. Sugars and sugar alcohols appeared as white spots against a brown background.

\section{RESULTS}

Purification of $M T L D H$. The results of a typical purification are shown in Table 1. A sample of $50 \mu \mathrm{g}$ of the final preparation gave a single protein band after SDS-PAGE. PAGE of the native enzyme also gave a single protein band which corresponded with the band stained for MTLDH activity. 
Table 1. Purification procedure for mannitol dehydrogenase

\begin{tabular}{|c|c|c|c|c|c|}
\hline Fraction & $\begin{array}{l}\text { Volume } \\
\text { (ml) }\end{array}$ & $\begin{array}{l}\text { Protein } \\
\text { content } \\
\left(\mathrm{mg} \mathrm{ml}^{-1}\right)\end{array}$ & $\begin{array}{c}\text { Specific } \\
\text { activity } \\
\text { (units } \mathrm{mg}^{-1} \text { ) }\end{array}$ & $\begin{array}{l}\text { Yield } \\
(\%)\end{array}$ & $\begin{array}{l}\text { Purification } \\
\text { (fold) }\end{array}$ \\
\hline Crude extract & 225 & $23 \cdot 6$ & $1 \cdot 032$ & 100 & $1 \cdot 00$ \\
\hline $\begin{array}{l}\text { Protamine sulphate precipitate } \\
\left.45-80 \% \text { (sat. }\left(\mathrm{NH}_{4}\right)_{2} \mathrm{SO}_{4}\right)\end{array}$ & 213 & $21 \cdot 7$ & $1 \cdot 128$ & $95 \cdot 2$ & 1.09 \\
\hline $\begin{array}{l}\text { precipitate } \\
\text { Concentrated Sephadex G100 }\end{array}$ & $8 \cdot 7$ & $65 \cdot 4$ & $2 \cdot 388$ & $24 \cdot 8$ & $2 \cdot 31$ \\
\hline $\begin{array}{l}\text { eluate } \\
\text { DEAE Sephadex A50 eluate } \\
\text { Concentrated Matrex Red eluate }\end{array}$ & $\begin{array}{r}7 \cdot 7 \\
27 \cdot 5 \\
2 \cdot 1\end{array}$ & $\begin{array}{l}16 \cdot 6 \\
0 \cdot 098 \\
0.44\end{array}$ & $\begin{array}{c}3 \cdot 954 \\
42 \cdot 42 \\
194 \cdot 40\end{array}$ & $\begin{array}{l}9 \cdot 27 \\
2 \cdot 10 \\
3 \cdot 27\end{array}$ & $\begin{array}{r}3 \cdot 83 \\
41 \cdot 10 \\
188 \cdot 40\end{array}$ \\
\hline
\end{tabular}

Table 2. Kinetic parameters of mannitol dehydrogenase at optimal $\mathrm{pH}$ and $\mathrm{pH} 7 \cdot 0$

Values are means of at least two determinations with less than $10 \%$ variation between replicates.

\begin{tabular}{|c|c|c|c|}
\hline Reaction & $\mathrm{pH}$ & $\begin{array}{c}K_{\mathrm{m}} \\
(\mathrm{mM})\end{array}$ & $\begin{array}{c}V_{\max } \\
{\left[\mu \mathrm{mol} \mathrm{min}^{-1}\right.} \\
\left.(\mathrm{mg} \text { protein })^{-1}\right]\end{array}$ \\
\hline Fructose reduction & $7 \cdot 0$ (optimal) & $\begin{array}{ll}\text { Fructose } & 1.2 \times 10^{3} \\
\text { NADPH } & 3.85 \times 10^{-2}\end{array}$ & 591 \\
\hline Mannitol oxidation & $10 \cdot 25$ (optimal) & $\begin{array}{l}\text { Mannitol } \quad 16.2 \\
\text { NADP } \quad 8.2 \times 10^{-2}\end{array}$ & $70 \cdot 2$ \\
\hline & $7 \cdot 0$ & $\begin{array}{lr}\text { Mannitol } & 16.2 \\
\text { NADP } & 3.6 \times 10^{-2}\end{array}$ & $5 \cdot 0$ \\
\hline
\end{tabular}

$M_{r}$ determination. SDS-PAGE of the purified enzyme gave a value of 29500 for the subunit $M_{\mathrm{r}}$. The $M_{\mathrm{r}}$ of the native enzyme was 115000 by gel filtration and 130000 by rate zonal ultracentrifugation. The sedimentation coefficient $\left(s_{20, w}\right)$ of the native molecule was $6.5 \mathrm{~S}$. Values are means of at least two determinations, showing less than $5 \%$ variation.

Specificity. No reaction was observed when D-fructose was replaced with D-glucose, Dgalactose, L-sorbose or D-fructose 6-phosphate. When mannitol was replaced by sorbitol, the reaction rate was reduced to $7.7 \%$ of the value with mannitol. No reaction was observed with Dgalactitol, ribitol, L-arabitol or erythritol. NADP and NADPH could not be replaced by NAD and NADH. With D-mannitol as substrate, D-fructose was identified as the sole product by paper chromatography; with D-fructose as substrate, D-mannitol was the sole product.

Kinetics. Linear Lineweaver-Burk and Eadie-Hofstee plots were obtained with all substrates in both directions of the reaction. The values for $V_{\max }$ and apparent $K_{\mathrm{m}}$ were calculated from the plots. The $\mathrm{pH}$ optima for fructose reduction and mannitol oxidation were 7.0 and 10.25 respectively. Table 2 summarizes the data for the reaction.

The $K_{\mathrm{m}}$ for mannitol was relatively constant at $16.2 \mathrm{mM}$ over the pH range. Similarly, the $K_{\mathrm{m}}$ for NADPH varied between $17.0 \mu \mathrm{M}$ at $\mathrm{pH} 7.25$ and $19.2 \mu \mathrm{M}$ at $\mathrm{pH} 10.25$. The $K_{\mathrm{m}}$ for NADP rose from $36 \mu \mathrm{M}$ at $\mathrm{pH} 7.5$ to $86 \mu \mathrm{M}$ at $\mathrm{pH} 10.5$. Concentrations of NADP above $1.5 \mathrm{~mm}$ caused inhibition.

Product inhibition. With fructose as substrate and NADPH at a constant, non-saturating concentration $(6.9 \mu \mathrm{M})$, added NADP inhibited the reaction. A NADP/NADPH ratio of approximately 38 was necessary for $50 \%$ inhibition of the reaction (Fig. 1). In the direction of mannitol oxidation, NADPH inhibited the reaction strongly (Fig. 1). With a saturating concentration of NADP $(1 \mathrm{mM}), 50 \%$ inhibition was seen at a NADPH/NADP ratio of $0 \cdot 1$, and with a non-saturating concentration of NADP $(20 \mu \mathrm{M}), 50 \%$ inhibition was seen at a ratio of $0 \cdot 45$. These data were obtained at $\mathrm{pH} 7 \cdot 5$. 

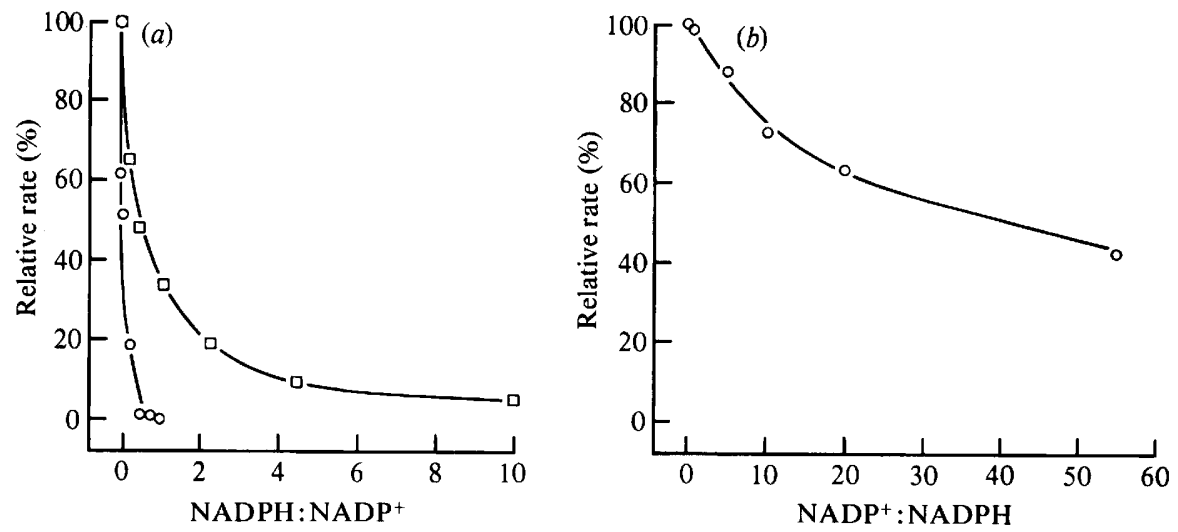

Fig. 1. Effect of coenzyme product on MTLDH reaction rate. (a) Effect of increasing NADPH/NADP ratio on rate of mannitol oxidation at $\mathrm{pH} 7 \cdot 5$, with a saturating mannitol concentration $(200 \mathrm{mM})$ and a saturating $(1 \mathrm{mM} ; O)$ or non-saturating $(20 \mu \mathrm{M} ; \square)$ NADP concentration. $100 \%=0.61 \mu \mathrm{mol} \mathrm{min}^{-1}$ (mg protein $)^{-1}$. (b) Effect of increasing NADP/NADPH ratio on the rate of fructose reduction at $\mathrm{pH} 7 \cdot 5$, with a saturating fructose concentration $(800 \mathrm{mM})$ and non-saturating NADPH concentration $(6.9 \mu \mathrm{M}) .100 \%=149 \mu \mathrm{mol} \mathrm{min}^{-1}(\mathrm{mg} \text { protein })^{-1}$.

Table 3. Concentrations of reactants and products to determine $k_{\text {eq }}$ for mannitol dehydrogenase

Values are means of two determinations, showing less than $10 \%$ variation between replicates.

$\begin{array}{lcc}\text { Reactant/product } & \begin{array}{c}\text { Initial concn } \\ (\mathrm{M})\end{array} & \begin{array}{c}\text { Final concn } \\ (\mathrm{M})\end{array} \\ \text { Mannitol } & 5.00 \times 10^{-4} & 4.70 \times 10^{-4} \\ \text { NADP } & 3.69 \times 10^{-5} & 6.52 \times 10^{-6} \\ \text { Fructose } & 0 & 3.04 \times 10^{-5} \\ \text { NADPH } & 0 & 3.04 \times 10^{-5} \\ \mathrm{H}^{+} & 6.61 \times 10^{-11} & 6.61 \times 10^{-11}\end{array}$

Determination of $k_{\text {eq }}$. The initial and final concentrations of reactants and products for the reaction are given in Table 3. The final concentrations obtained give:

$$
k_{\text {eq }}=\frac{[\text { fructose }][\mathrm{NADPH}]\left[\mathrm{H}^{+}\right]}{[\text {mannitol][NADP }]}=1.99 \times 10^{-11} \mathrm{M}
$$

\section{DISCUSSION}

A homogeneous preparation of MTLDH, as indicated by native and SDS-PAGE, has been isolated from $A$. bisporus fruit bodies. The subunit $M_{\mathrm{r}}$ of 29500 and native $M_{\mathrm{r}}$ of $115000-130000$ suggest that the enzyme is a tetramer. The value of 40000 for the native $M_{\mathrm{r}}$ reported by Ruffner et al. (1978) thus appears to be based on the subunit value.

The high specificity of MTLDH for NADP(H) as coenzyme, and for D-fructose as substrate, confirms previous findings (Ruffner et al., 1978), although differences in polyol specificity were found. No detectable activity was observed with L-arabitol in the present investigation, and activity with sorbitol was $7.7 \%$ of that with D-mannitol. Ruffner et al. (1978) reported values of $2 \%$ and $21 \%$ respectively for the same polyols; these observations may have resulted from contaminating enzyme activities. Since there have been no reports of significant levels of polyols other than mannitol in $A$. bisporus, it is unlikely that the activity of MTLDH against sorbitol is physiologically important. 
Concentrations of fructose above $1.2 \mathrm{M}$ at $\mathrm{pH}$ values below $\mathrm{pH} \mathrm{9.9,} \mathrm{and} \mathrm{above} 0.8 \mathrm{M}$ above $\mathrm{pH} 9.9$, resulted in substrate inhibition. Since substrate inhibition was seen at fructose concentrations similar in value to the $K_{\mathrm{m}}$, saturation of the enzyme with this substrate was not possible under experimental conditions. Because of this, a fructose concentration of $800 \mathrm{~mm}$ was used in assays, which gave a rate of fructose reduction which was $90 \%$ of that at the optimum fructose concentration. Using this fructose concentration and varying the NADPH concentration gave apparent first order kinetics with respect to NADPH. Apparent values for $K_{\mathrm{m}}$ and $V_{\max }$ of $17 \mu \mathrm{M}$ and $240 \mu \mathrm{mol} \mathrm{min}^{-1}$ (mg protein $)^{-1}$ were calculated from these data. Double reciprocal plots of initial velocity against the concentration of one substrate at a series of fixed concentrations of a second substrate yield a set of parallel lines (see for example Velick \& Vavra, 1962). By using the $V_{\max }$ obtained by varying the fructose concentration in the presence of a saturating concentration of NADPH [591 $\left.\mu \mathrm{mol} \mathrm{min}^{-1}(\mathrm{mg} \text { protein })^{-1}\right]$ as the intercept for the construction of a double reciprocal plot parallel to that obtained by varying the NADPH concentration in the presence of $800 \mathrm{mM}$-fructose, a corrected $K_{\mathrm{m}}$ of $38.5 \mu \mathrm{M}$ was obtained for NADPH.

The parallel double reciprocal plots imply a ping-pong mechanism with the Haldane relationship:

$$
k_{\mathrm{eq}}=\left(\frac{V^{\mathrm{f}}}{V^{\mathrm{r}}}\right)^{2} \cdot \frac{K_{\mathrm{m}}^{\mathrm{p}} K_{\mathrm{m}}^{\mathrm{Q}}}{K_{\mathrm{m}}^{\mathrm{A}} K_{\mathrm{m}}^{\mathrm{B}}}
$$

If the kinetic parameters for $\mathrm{pH} 7 \cdot 0$ are substituted and the $\mathrm{H}^{+}$concentration is corrected for, the $k_{\text {eq }}$ is calculated to be $5.7 \times 10^{-10}$. This is close to the value arrived at by equilibrium measurements, and thus supports the value obtained for the $K_{\mathrm{m}}$ for fructose.

The $K_{\mathrm{m}}$ values for coenzymes given here (Table 2) are similar to those reported previously. The $K_{\mathrm{m}}$ for mannitol is half that reported by Ruffner et al. (1978) (34 mM). The value of $0.46 \mathrm{mM}$ found by Edmundowicz \& Wriston (1963) may have been low because of the impurity of the enzyme preparation. The $K_{\mathrm{m}}$ for fructose shows larger discrepancies; the values of Ruffner $e t$ al. (1978) (190 mM) and Edmundowicz \& Wriston (1963) (1.4 mM) are considerably lower than the $1.2 \mathrm{M}$ found in this investigation. However, high $K_{\mathrm{m}}$ values have been reported for similar enzymes; a $K_{\mathrm{m}}$ of $1.0 \mathrm{M}$ for fructose was reported for the MTLDH of Cephalosporium chrysogenum (Birken \& Pisano, 1976). The high value obtained in the present study indicates that the physiological rate of mannitol production by the reaction must be directly proportional to the concentration of fructose, assuming that there are no other constraints on activity. As the overall fructose concentration in the cell appears to be no higher than $3 \mathrm{mM}$ (Hammond, 1985b), compartmentation of mannitol synthesis must be presumed to exist; otherwise the physiological role of the enzyme would be in doubt since it would be operating at less than $1 \%$ of its $V_{\max }$.

Physiological mannitol oxidation should occur at a rate almost independent of mannitol concentration in the fruit body, since the $K_{\mathrm{m}}$ is considerably lower than the observed intracellular concentration (Hammond, 1985 b). Thus the physiologically important reaction, fructose reduction, can be subject to far greater rate control by substrate concentration than the reverse reaction.

Ruffner et al. (1978) placed emphasis on the sensitivity of fructose reduction to NADP concentration. Some sensitivity was observed here; however, a non-physiological NADP/ NADPH ratio was necessary to give $50 \%$ inhibition. The NADP/NADPH ratio of approximately $1: 1$ estimated to be present in vivo (Hammond, 1985b) suggests that inhibition is unlikely to occur unless there is compartmentation of the oxidized and reduced forms of the coenzyme.

In contrast, the present study indicates that mannitol oxidation is very sensitive to NADPH concentration. The concentrations of NADP and NADPH in A. bisporus fruit bodies were reported to be between 50 and $180 \mu \mathrm{M}$ (Hammond, 1985b). At this NADP concentration, $50 \%$ inhibition of the reaction would be achieved with an NADPH/NADP ratio of about 0.25 , and the in vivo ratio would give about $70 \%$ inhibition (see Fig. 1a). Hence in the physiological $\mathrm{NADP}(\mathrm{H})$ concentration range, small changes in the redox state of the coenzyme will have a considerable effect on the rate of mannitol oxidation. 
Under normal conditions of fruit body growth, it seems likely that the rate of mannitol synthesis is governed by the supply of fructose and NADPH. The $k_{\text {eq }}$ for the reaction shows that it is heavily displaced towards mannitol synthesis. Only under conditions of low NADPH relative to NADP would mannitol oxidation occur at a significant rate. Such conditions could occur after the fruit body has been harvested or during senescence, when mannitol concentrations in the fruit body are known to fall (Hammond \& Nichols, 1975; 1976).

N. M. was supported by a SERC CASE Research Studentship.

\section{REFERENCES}

Birken, S. \& Pisano, M. A. (1976). Purification and properties of a polyol dehydrogenase from Cephalosporium chrysogenum. Journal of Bacteriology 125, 225-232.

Edmundowicz, J. M. \& WRiston, J. C. (1963). Mannitol dehydrogenase from Agaricus campestris. Journal of Biological Chemistry 238, 3539-3541.

HAMmOND, J. B. W. (1985a). Glucose-6-phosphate dehydrogenase from Agaricus bisporus: purification and properties. Journal of General Microbiology 131, 321-328.

HaMmond, J. B. W. (1985b). Sugar, sugar phosphate and NADP(H) levels in Agaricus bisporus fruit bodies. Journal of General Microbiology 131, 329-333.

Hammond, J. B. W. \& Nichols, R. (1975). Changes in respiration and soluble carbohydrates during the post-harvest storage of mushrooms (Agaricus bisporus). Journal of the Science of Food and Agriculture 26, 835-842:
Hammond, J. B. W. \& Nichols, R. (1976). Carbohydrate metabolism in Agaricus bisporus (Lange) Sing.: changes in soluble carbohydrates during growth of mycelium and sporophore. Journal of General Microbiology 93, 309-320.

RAST, D. (1965). Zur stoffwechselphysiologischen Bedeutung von Mannit und Trehalose in Agaricus bisporus (eine gaschromatographische Studie). Planta 64, 81-93.

RUfFNeR, H. P., RASt, D., TOBleR, H. \& Karesch, H. (1978). Purification and properties of mannitol dehydrogenase from Agaricus bisporus sporocarps. Phytochemistry 17, 865-868.

Velick, S. F. \& VaVRa, J. (1962). Kinetic and equilibrium analysis of the glutamate oxalacetate transaminase mechanism. Journal of Biological Chemistry 237, 2109-2122. 